\title{
Accounting Recognition of Asset Abandonment and Site Restoration
}

\author{
Rena Maya Cahyanti ${ }^{1 *}$ and Aruna Wirjolukito ${ }^{2}$ \\ ${ }^{1,2}$ Universitas Indonesia, Depok, Indonesia
}

\begin{abstract}
This research will discuss the recognition of asset abandonment and site restoration or commonly known as ARO (Asset Retirement Obligation) in oil and gas company. The purpose is to be able to provide an overview that can be used by companies in calculating ARO that must be paid at the end of the contract period. The formulation of the problem is which method is used to determining the amount of asset abandonment and site restoration or ARO that is appropriate to overcome the potential problems that arise at the end of the contract period. This research is carried out by using a mixed method in analyzing the findings, so it will find the in-depth findings which will be useful to assist the company's management in making decisions. Signal theory is a theory that will be chosen in this research. This research will use three stages of analysis, such as descriptive analysis, content analysis, and constant comparative analysis. Based on the results it might found that the recognition of asset abandonment and site restoration carried out according to regulations apply. While company uses the method of calculating liabilities based on future values that is continually calculate in present value.
\end{abstract}

Keywords: Contingent Liabilities, Liability For Asset Abandonment, Provisions, Site Restoration.

\section{Introduction}

Earth is endowed with very diverse natural resources, one of them is resources from oil and gas and non-oil and gas. Indonesia itself is one of the countries that is endowed with these two kinds of resources abundantly. This statement is in accordance with non-tax state revenue data which can be seen further in the table:

Table 1 Non-Tax State Revenues, Year 2015-2016

\begin{tabular}{|c|c|c|c|c|}
\hline \multirow[b]{2}{*}{ Uraian } & \multirow{2}{*}{$\begin{array}{c}2015 \\
\text { LKPP } \\
\text { Unaudited }\end{array}$} & \multicolumn{3}{|c|}{2016} \\
\hline & & APBN & APBNP & $\begin{array}{l}\% \text { thd } \\
\text { APBN }\end{array}$ \\
\hline 1 & 2 & 3 & 4 & $5=4 / 3$ \\
\hline A. Pendapatan Penerimaan Sumber Daya Alam & $100.971,9$ & $124.894,0$ & $90.524,4$ & $\mathbf{7 2 , 5}$ \\
\hline 1. Pendapatan Minyak dan Gas Bumi & $78.170,5$ & $78.617,4$ & $68.688,1$ & 87,4 \\
\hline a. Pendapatan Minyak Bumi & $47.987,4$ & $60.287,1$ & $51 \cdot 328,1$ & 85,1 \\
\hline b. Pendapatan Gas Bumi & $30.183,0$ & $18.330,3$ & $17 \cdot 360,0$ & 94,7 \\
\hline 2. Pendapatan Non-Minyak dan Gas Bumi & $22.801,4$ & $46.276,5$ & $21.836,3$ & 47,2 \\
\hline a. Pendapatan Pertambangan umum & $17.682,9$ & $40.820,2$ & $16.539,9$ & 40,5 \\
\hline b. Pendapatan Kehutanan & $4.156,5$ & $4.030,6$ & $3.972,7$ & 98,6 \\
\hline c. Pendapatan Perikanan & 79,3 & 693,0 & 693,0 & 100,0 \\
\hline d. Pendapatan Panas Bumi & 882,7 & 732,8 & 630,7 & 86,1 \\
\hline B. Pendapatan Bagian Pemerintah atas Laba BUMN & $37.643,7$ & $34.164,0$ & $34.164,0$ & 100,0 \\
\hline C. PNBP Lainnya & $81.697,4$ & $79.431,5$ & $84.123,9$ & 105,9 \\
\hline D. Pendapatan BLU & $35 \cdot 315,5$ & $35 \cdot 359,9$ & $36.271,2$ & 102,6 \\
\hline JUMLAH & $255.628,5$ & $273.849,4$ & $245.08{ }_{3}, 6$ & 89,5 \\
\hline
\end{tabular}

Source: https://www.kemenkeu.go.id/media/6634/nota-keuangan-rapbn-2016.pdf. (Kementerian Keuangan Republik Indonesia, 2016)

From the table above, country's revenues from the natural resources sector are still very high and become the highest revenue which comes from oil and gas resources in Indonesia. Revenue in this sector is apparently high but is comparable to the consequences that must be borne by the Country from this sector, one example is the

\footnotetext{
* Corresponding author. Email address : renamayaa@gmail.com
} 
case of Lapindo's mud. This case is one of the cases arising from an error in the work process in the oil and gas industry that occurred at the Lapindo well location in Sidoarjo (Lapindo Sidoarjo Report 2014, 2014). This Lapindo case in 2009 was considered a national disaster, even though this should be the responsibility of the company itself. As an industry engaged in the concession area, it should already know about natural impacts and risks that will arise from every drilling aspects (Kusumawati, 2015).

Because of this background, regulation for asset abandonment and site restoration or commonly known as ARO (Asset Retirement Obligation) is established. This obligation is required for the companies that use concession land to make a reserve for the estimated cost to replace the site like the first time. This is in accordance with what is disclosed in Indonesian GAAP 57 and mention which is the entity has a constructive current obligation for the past events (IAI, 2016).

Although the effect of these obligations is not significant on the company's performance, the costs incurred are quite large. So the liability that will arise is also quite large. In accounting this obligation is recorded as an asset or capitalized. But the value of this obligation is also called provision because it is only an estimate (IAI, 2016). Because of that the research on ARO was chosen because it was in accordance with the background described earlier, that the amount of ARO obligations was still estimating. Where to measure reliably it requires many factors that may be different even in the same industry. While the uniformity of accounting standards with the company's financial statements requires IFRS coverage and one of the IFRS that has been thoroughly adopted is Indonesia GAAP 57 (Purba, 2009). Because of this rationale, it was chosen to make a research entitled "Accounting Recognition of Asset Abandonment and Site Restoration in the Upstream Oil and Gas Company".

\section{Research's Purposes}

Purpose of this research is to be able to find out the problems that exist in the company regarding the method that can be used by company to calculate asset abandonment and site restoration or commonly known as ARO (Asset Retirement Obligation) which must be paid by the company at the end of the company's contract. This purpose is to find out whether the amount estimated is considered to reveal the real amount that must be recognized by the company that is useful for company's decision making.

\section{The Formulation Problem}

Formulation of the problem in this research is related to asset abandonment and site restoration or ARO (Asset Retirement Obligation) for all companies that use land concessions, especially companies in the upstream oil and gas company, is obliged to restore the land at the end of the contract period. Thus, the questions that will arise from the problem of this research, is:

- How is the right method that can be used by the company to calculate the ARO (Asset Retirement Obligation) which must be paid by the company at the end of the contract period so it is considered the capable of actual amount by company?

\section{Benefits of the Research}

According to Ellet, a research is expected to have benefits to improve the positive factors that exist for decision making, to know the core of existing problems, and to be useful in terms of corporate strategic in decision making (Ellet, 2009). Whereas for this research, the research benefits are expected that can be elaborated, such as:

1. Practical Benefits

Provide a positive evaluation for the company in relation to the recognition of the obligation for asset abandonment and site restoration or ARO (Asset Retirement Obligation). Optimizing the solutions obtained from research findings for the future is useful for companies to be able to use the right method in recognizing the 
amount of ARO (Asset Retirement Obligation). As well as helping shareholders in making corporate strategic decisions.

2. Academic Benefits

This research is expected to be useful for future research to be able to test and find out the right and best method in finding the magnitude of the obligation for asset abandonment and site restoration or ARO (Asset Retirement Obligation), so that all uncertainties in the future can be measured by reliable way.

\section{Literature Study}

The literature chosen in this research is all things that are related and can explain asset abandonment and site restoration in more detail and depth based on the opinions of experts. The literature review will also focus on explaining contingent liabilities and provisions covered by Indonesian GAAP 57. The theory which is chosen in this research is signal theory. This theory is chosen because it can provide guidance for investors about how management views the company in the future (Brigham \& Houston, 2001). Based on this theory, it can be considered that there is a link between external and internal parties, which causes a company to be required to be able to present financial statements representative to reflect the best condition of the company.

This definition can be considered to explaining the reasons why a company has an obligation to provide financial statement information to internal parties and external parties. Disclosure of the information to external parties is related to the reason that the company's internal parties knew more about the company's core activities and future business projects compared to the external parties of the company. Then the company must protect its company from the asymmetrical information. One method to reduce asymmetric information is giving a signal to external parties of the company (Arifin, 2005). Because of signal theory is closely related to the availability of information, then all the information referred to a company performance report that will show an overall picture of the company's activities in a period, which is commonly known as a company's financial statements (Kretarto, 2001).

\section{Previous Research}

Several previous studies used by researchers as comparative data in this research is a summary article entitled Accounting for Asset Retirement Obligations conducted by Eric Alexander and Ronald Hiner. This article contains an explanation of the FASB issued statement no.143 regarding Asset Retirement Obligations (ARO), in which the author explains the important points related to Asset Retirement Obligations (ARO) in the company's financial statements (Alexander \& Hiner, 2001). Where in the article just explained the important points of the FASB no.143 without giving any relevant examples faced by the company in relation to recording this.

Whereas the relation to the obligations regarding the recognition and measurement of provisions, contingent liabilities, and contingent assets and to ensure adequate information has been disclosed in financial statements that are in accordance with the current financial accounting standards can be seen in the book written by Purba (Purba, 2009). In this book, it is explained that the current Indonesian financial accounting standards are using the Statement of Financial Accounting Standards (Indonesian GAAP) which will be converged and can adopt IFRS as a whole. One of the IRFS that has been thoroughly adopted by the Indonesian GAAP is Indonesian GAAP No.57 which also regulates Asset Retirement Oblihation (ARO) in it.

\section{Asset Abandonment and Site Restoration}

Obligation for asset abandonment and site restoration which is commonly known as ARO (Asset Retirement Obligation) is explained implicitly in Indonesian GAAP 16 concerning fixed assets, Indonesian GAAP 57 concerning provisions, contingent liabilities, and contingent assets, and in IFRS 19 regarding the application of the restatement approach. An entity has an obligation to recognize the obligation for asset 
abandonment and site restoration or ARO (Asset Retirement Obligation) when the entity has legal obligations that are binding on long-term assets which later the entity is also obliged to estimate its obligations (IAI, 2016).

Whereas according to the Financial Accounting Standard Board in FASB 143 which effectively replaces Financial Accounting Standard (FAS) 19 paragraph 37, ARO (Asset Retirement Obligation) is defined as a legal obligation relating to the withdrawal of tangible assets that have a long life where the time or method of settlement is possible depends on future events, which means that the future event may not be in the company's control (FASB, 2001). A company must recognize responsibility for the Asset Retirement Obligation (ARO) in the period, for example at the time of acquisition. Assets which are equivalent to initial liabilities are added to the balance sheet and then depreciated by a method of depreciation over the useful life of the asset. The result is an increase in assets and liabilities that exist, while the expected total cost is recognized from time to time, on an accrual basis which will always increase in plurality (FASB, 2001).

\section{Research Methodology}

This research has a purpose to answer research questions regarding the methods carried out by the company to recognize the obligation for asset abandonment and site restoration or ARO (Asset Retirement Obligation). The obligation for asset abandonment and site restoration or ARO (Asset Retirement Obligation) which is determined as an estimation so that its obligation could be able to represent the reliability of the company's financial statements in more depth in order to explain and evaluate, identify and analyze, and provide other recommendations according to this obligation. So that, in the below will be discussed about the research approach used, research instrument, data analysis, and unit of analysis which is examined in this research.

\section{$\underline{\text { Research Approach }}$}

This research will use a mixed-method approach. It is a method to approach the research in between qualitative and quantitative. The mixed-method is carried out to collect data, which comes through in-depth or qualitative interviews and also by using quantitative methods which will be used for further analysis from supporting documents and it could be obtained during the research process. Mixed-method is chosen because they will produce richer research results, and can answer important questions related to research problems. These supporting documents can be contained such as monthly and annual financial statement as well as audit report form the company.

\section{Research Instruments}

Research instruments chosen by the authors in the preparation of this research, such as:

1. Interview

Interview is the first data collection technique to be conducted in order to collect data directly with the related parties of this research.

2. Observation

Observation will be carried out as a further analysis to analyze all documents and data that have been collected related to this research.

3. Documentation

Documentation aims to research all of the documents in the company that relate to research problems. The documentation which is needed in this research such as financial statement or audit report, contracts with related parties, as well as supporting data on the calculation of financial statements such as work paper made.

4. Corporate Webite 
Website owned by the party has a purpose in order to complete the data that will be needed in this research which can be used as a supporting document to seek in-depth data where the research takes place.

Data Analysis

Data analysis which is relate to this research, such as:

1. Descriptive Qualitative Analysis

Descriptive qualitative analysis is one of the qualitative approaches that used as research procedures to produce descriptive data in the form of written or oral data from people around (Moleong, 2006). This approach was carried out because in this research initially began in events that occurred scientifically without any coercion or intervention in the company where the research take place.

2. Content Analysis

According to Shelley \& Krippendorff in his book, mentioning that:

"Content analysis is a research technique for making replicable and valid inferences from texts (or other meaningful matter) to the context of their use" (Shelley \& Krippendorff, 2006)..

So in relation to this research, content analysis has its own way to analyze information where the method comes directly from the object of research analysis, which is the company's financial statements that will become something to be analyzed.

3. Constant Comparative Analysis

Constant comparative analysis is analyze method by comparing the events that had never happened before investigation, and continuously throughout the research was conducted and identifies the core variables of the research. This analysis according to Glaser is a variable which is a variable that is sought and tested again on each research instrument (Glaser, 1978).

\section{Unit of Analysis}

Unit of analysis in this research is the "Multiple Embedded" unit of analysis. Where the object of research will be focus on a unit of analysis in the company that use concession land in their businesses, such as a company that engaged in the upstream oil and gas company.

\section{Results}

This section will be described and explained about the answers of the results of the research regarding the recognition of asset abandonment and site restoration or ARO (Asset Retirement Obligation) based on the analysis of data and research instruments discussed in the previous chapter. This part will also discuss the research objectives to be achieved and methods that can be used by companies in calculating the obligation for asset abandonment and site restoration or ARO (Asset Retirement Obligation) which must be paid by the company at the end of the contract period that can be done with the right method. So in the future it will also be able to estimate the value of the obligation for asset abandonment and site restoration or ARO (Asset Retirement Obligation) which is considered capable of representing actual values that must be recognized by the company so that the financial statements are reliable and can be useful for corporate decision making.

\section{Findings}

This research analyzed the best method to be used in the upstream oil and gas company to calculate the obligation for asset abandonment and site restoration or commonly known as ARO (Asset Retirement Obligation) which will be recognized related to its business. This is to find out whether the amount of the reserved obligation 
is sufficient to cover all potential problems related to the business being carried out. The evaluation component of the method used to calculate asset abandonment and site restoration obligations can be seen through a history of similar transactions seen through Cooperation Contracts or better known as Profit Sharing Contracts (PSC), information contained in financial statement or audit report and data given by the expert as a third person in a particular case, or in it includes additional information provided after the balance sheet date. Here are the results from the analysis of each component to see what the underlying company in determining the value of liabilities of asset abandonment and site restoration or ARO (Asset Retirement Obligation) that separate in two sources, specifically in Profit Sharing Contract and Financial Statement or Audit Report.

Table 2 Obligations for Asset Abandonment and Site Restoration or ARO

\begin{tabular}{ll}
\hline Production Sharing Contracts (PSC) & \multicolumn{1}{c}{ Interview Results } \\
\hline Regulated in PSC in Article & Although the value of the ARO (Asset \\
Abandonment and Site Restoration, and & Retirement Obligation) is still an estimation or \\
in the future this obligation will be & provision, but this obligation on ARO (Asset \\
included in the component of operating & Retirement Obligation) must be recognized by \\
costs that are required to cover all & the company in its financial statements. \\
expenses incurred at the time of the & Because if it has been determined in a profit \\
abandonment of the exploration site well & sharing contract or PSC, then the obligation \\
along with the equipment inside. & which is the nature of this estimation is highly \\
& probable to do so that it will must be mention \\
in the balance sheet (Respondent 1, 2019).
\end{tabular}

Therefore, based on the data collected in this study, the assessment of the provision of liability for asset abandonment and site restoration carried out by the company can be concluded based on the following table:

Table 3 Recognition of Asset Retirement Obligation for in the Upstream Oil and Gas Company

\begin{tabular}{|c|c|c|c|}
\hline Issues & Implementations & Field Practices & Findings \\
\hline $\begin{array}{l}\text { Recognition of } \\
\text { asset abandonment } \\
\text { and site restoration } \\
\text { (Asset Retirement } \\
\text { Obligation/ ARO) }\end{array}$ & $\begin{array}{l}\text { The company as } \\
\text { one of the oil and } \\
\text { gas contractors } \\
\text { recognizes ARO } \\
\text { by using a } \\
\text { predetermined } \\
\text { method, which is } \\
\text { based on the } \\
\text { formula of future } \\
\text { value (FV) which } \\
\text { is after that has to } \\
\text { be calculated in the } \\
\text { present value (PV) } \\
\text { using the inflation } \\
\text { rate and discount } \\
\text { rate. }\end{array}$ & $\begin{array}{l}\text { Based on the } \\
\text { practices carried } \\
\text { out in the } \\
\text { company, } \\
\text { formula using } \\
\text { future value (FV) } \\
\text { is used because the } \\
\text { company needs to } \\
\text { know the value } \\
\text { that must be } \\
\text { reserved in the } \\
\text { future, then it is } \\
\text { calculated again to } \\
\text { get its present } \\
\text { value (Brady, } \\
\text { Chang, Jennings, } \\
\text { Shappard, \& } \\
\text { Ogden, 2011). }\end{array}$ & $\begin{array}{l}\text { There are no } \\
\text { suspicious } \\
\text { findings } \\
\text { considering that all } \\
\text { data has been } \\
\text { presented well in } \\
\text { the financial } \\
\text { statements and } \\
\text { audit report of the } \\
\text { company for every } \\
\text { year. }\end{array}$ \\
\hline
\end{tabular}




\section{Discussion}

Profit Sharing Contract (PSC)

Profit sharing contract is a component of the first assessment that will be discussed where this research takes a comparison of the Profit Sharing Contract (PSC) owned by one of the subsidiary in the upstream oil and gas company. Where the contract can be used as a measurement tool for determining the value of the obligation for asset abandonment and site restoration on other contracts for similar business sectors by considering the similarity of location types or other matters.

Based on regulations made by the Indonesian government regarding the obligation for asset abandonment and site restoration or ARO (Asset Retirement Obligation), it is still not strictly regulated, because at the previous in Indonesia it only regulated the obligation of contractors to abandonment of locations and production facilities that were not used again. In the Government Regulation No.17 of 1974 it has been regulated regarding supervision of the upstream oil and gas business activities described in several articles concerning the matter of demolition for mining installations which have no longer been used with a time period that has also been determined by the government and there is also a prohibition on the contractors left wells that were no longer used before carrying out proper closure (Pemerintah Indonesia, 1974).

In 2010, BP MIGAS issued a regulation concerning the obligation to carry out asset restoration activities stipulated in KEP Number 0139 / BP00000 / 2010 / SO concerning Guidelines for Working Abandonment and Site Restoration (PTK-ASR) No.040-PTK-XI-2010 (SKK Migas, 2010). In the PTK-ASR it was stated that the Cooperation Contract Contractor (KKS Contractor) must do restoration and abandonment of all production facilities and other supporting facilities that have been used when the contract expires, when a part of the production area is returned, or when the production site is closed and abandoned (SKK Migas, 2010). So that at this time an explanation of the obligation for asset abandonment and site restoration or ARO (Asset Retirement Obligation) which is included in the site abandonment and restoration should be mentioned in a Cooperation Contract or PSC. In the contract it will be stated about the obligation of the contractor to be able to allocate the estimated amount of costs that will be needed in rehabilitating the environment and closing the abandoned wells (Husein, 2008).

In the upstream oil and gas companies generally have a PSC that regulates and states the obligation to demolish and restore assets, which in the data obtained in this research is mentioned in the Cooperation Contract in Article III concerning Accounting Methods To Be Used To Calculate - Recovery of Operating Costs, as follows:

Abandonment and Site Restoration Clausul

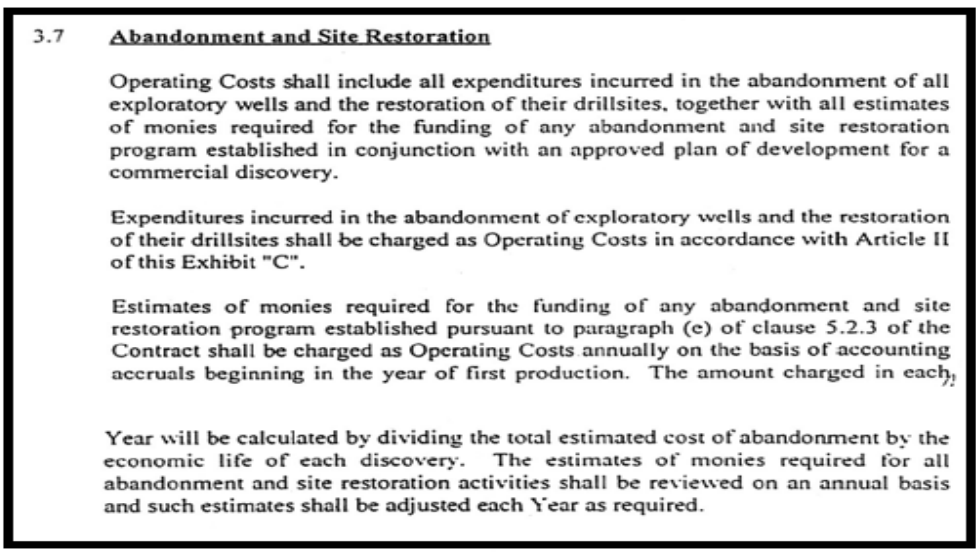

Figure 1 Obligation for Asset Abandonment and Site Restoration in Profit Sharing Contract 
Based on Figure 1, it could be seen that in a cooperation contract or PSC a company engaged in the upstream oil and gas company has an article concerning Abandonment and Site Restoration. Which regulates related liability for demolition and restoration of wells related to asset abandonment and site restoration. This Abandonment and Site Restoration is included in the operating costs, which must cover all expenses incurred when the exploration wells are abandoned along with the equipment inside them. This operating cost also contains an estimate of the estimated costs that will be incurred for the purposes of the completion of the contract and leaving and closing the exploration well. Expenditures for these obligations which are expenses for dismantling exploration wells can be charged as operating costs in accordance with the PSC contract.

The operational costs related to asset abandonment and site restoration are also mentioned in the Abandonment and Site Restoration article, and this one also in accordance with other articles mentioned in the PSC contract as follow:

\section{Operating Costs}

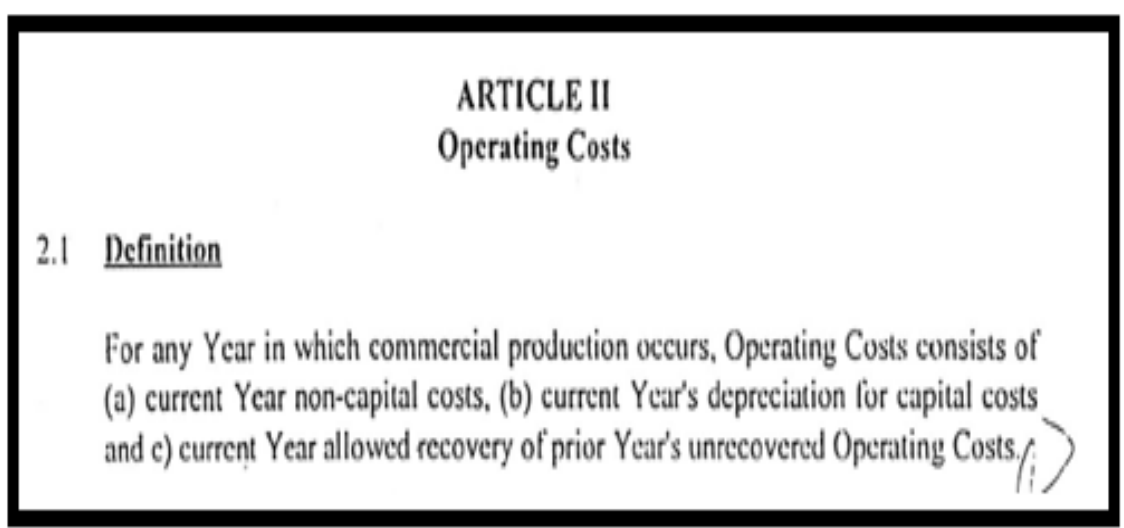

\section{Figure 2 Operating Cost}

Based on Figure 2, there are articles about the obligation for asset abandonment and site restoration or ARO (Asset Retirement Obligation) in a profit sharing contract or PSC, this is in accordance with what was mentioned by the informant (Respondent 2,2009 ) regarding this matter. The informant (Respondent 2, 2009) said that a PSC contract between the contractor and the government should contain an article relating to the obligation to dismantle and restore assets or ARO (Asset Retirement Obligation).

This is in accordance with what is stipulated in Decree No. KEP-0139 / BP00000 / 2010 / SO concerning Work Procedure (CAR) No. 040 / PTK / XI / 2010 which states that in the fourth generation of production sharing contract (PSC), it is obligatory to declare obligations related to the rehabilitation of the environment around the well site and to dismantle the entire installation and various types of equipment used before the location is abandoned.

Although in reality the cooperation contract used as this data was made before 2010, but in the contract already contained an article containing this obligation. So, based on this data and based on the data which obtained from the informants, the obligation for asset abandonment and site restoration or ARO (Asset Retirement Obligation) by the upstream oil and gas company must be recognized in the company's financial statements. This obligation is recognized based on all estimated costs calculated for the demolition of assets and restoration areas divided based on the estimated number of economic years from each well found. For this reason, the obligation for asset abandonment and site restoration or ARO (Asset Retirement Obligation) can be concluded according to the following table: 


\section{Financial Statement or Audit Report}

In Indonesian GAAP 57 which is concerning in "Provision, Contingent Liabilities and Contingent Assets" the obligation for asset abandonment and site restoration or ARO (Asset Retirement Obligation) is a legal obligation arising from the existence of a profit sharing contract or PSC contracts (IAI, 2016). Whereas based on the regulations per Indonesian Law, the regulations governing the ARO (Asset Retirement Obligation) are PTK-ASR No.040-PTK-XI-2010. One of public company's subsidiary engaged in the upstream oil and gas industry is also obliged to recognize these obligations as regulated by Indonesian GAAP 57 and also PTK-ASR No.040-PTK-XI2010.

In accordance with what has been discussed previously the obligation for asset abandonment and site restoration or ARO (Asset Retirement Obligation) is an obligation that arises in the future so that in its recognition must be calculated based on the value of future value based on estimated costs to be incurred which will then be changed to present value to know the present value. Furthermore, the assets must be debited first by the company and the company can enter all the components of the existing costs at the time of dismantling the asset into the value of the asset.

In the financial statements of this company, the assets of ARO (Asset Retirement Obligation) is comes up into oil and gas assets in the company's financial position / balance sheet. This is because the obligation arising as an ARO (Asset Retirement Obligation) is indeed inseparable from the oil and gas assets owned by the company. So if described in the financial statements of the companies of oil and gas assets are as follows:

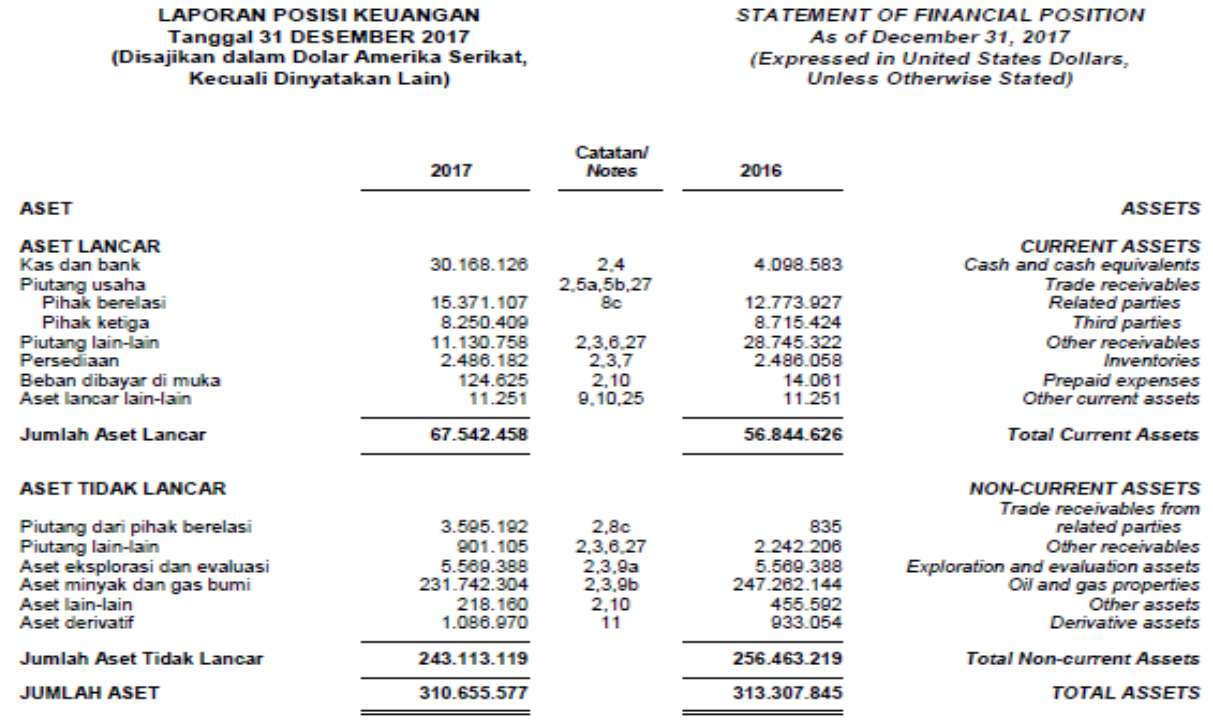

Figure 3 Oil and Gas Assets in the Company's Balance Sheet 


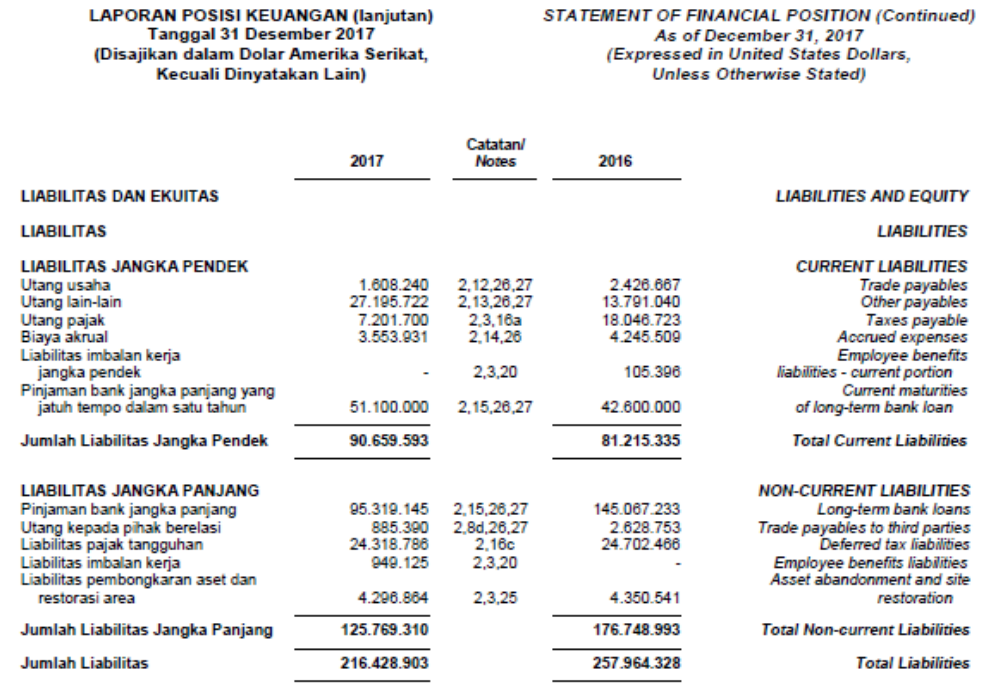

Figure 4 Asset Abandonment and Site Restoration's Liability

In this financial report, it is also explained that the company recognizes the obligation for asset abandonment and site restoration for oil and gas production facilities, wells, pipelines, and related assets in accordance with the terms of the profit sharing contract. The first estimation stage of the cost of asset abandonment and site restoration, is recognized as a component of acquisition costs, which are then depreciated or depleted using the unit of production method in line with the depreciation rates chosen by the company. In accordance with existing contracts, the remaining asset depreciation period for contract-based demolition costs is five years in 2017, considering that the contract period is up to 2022.

Based on the opinion of the informant (Respondent 3, 2019), which acts as an expert economist company states that demolition and asset transfer activities, and restoration of areas of oil and gas production facilities, wells, and pipelines and related assets occurring in the coming years according to the deadline for the contract period and if the contract is no longer extended. Estimates of the magnitude of these obligations have been assessed reliably by management regarding when the activity will be carried out, the extent to which the activity must be carried out, and also the technology that will be used in the future.

Whereas the viewed from the company's accounting expert's opinion on this obligation the presentation has been adjusted which will reflect the present value of the provision of drilling liabilities and transfer of assets, and restoration area at the financial position report date, where the company will also make an equal amount of value book of assets in question (Respondent 2, 2019). Then the opposite of recording or reversing the discount effect in calculating this provision is recognized as a funding cost.

The obligation for asset abandonment and site restoration in 2016 and 2017 is determined according to the interest rate agreed between the regulator (government) and the contractor (company), which is $6 \%$. The company in presenting these asset demolition liabilities is carried out in a net manner with an account that has been reserved through a Bank that has been determined by agreement. 


\begin{tabular}{|c|c|c|c|}
\hline Mutasi akun ini disajjikan sel & & The accour & are presented below: \\
\hline & 2017 & 2016 & \\
\hline Saldo awal & 10.247 .536 & 9.754 .416 & Beginning balance \\
\hline Akresi selama tahun berialan & 522.707 & 493.120 & Accretion during the year \\
\hline Saldo akhir & 10.770 .243 & 10.247 .536 & Ending balance \\
\hline Rekening yang dicadangkan & (6.473.379) & $(5.896 .995)$ & Escrow accounts \\
\hline Saldo akhir liabilitas & 4.296 .864 & 4.350 .541 & Liabilities ending balance \\
\hline
\end{tabular}

Figure 5 Asset Abandonment and Site Restoration Balance in 2017

Based on data from the balance of asset abandonment and site restoration presented in the financial report or audit report, the company is obtained from the financial statement numbers that have been adjusted with various audit adjustments in it. The initial balance amount in 2017 has been re-matched with the final balance in the 2016 financial statements as can be seen as follows:

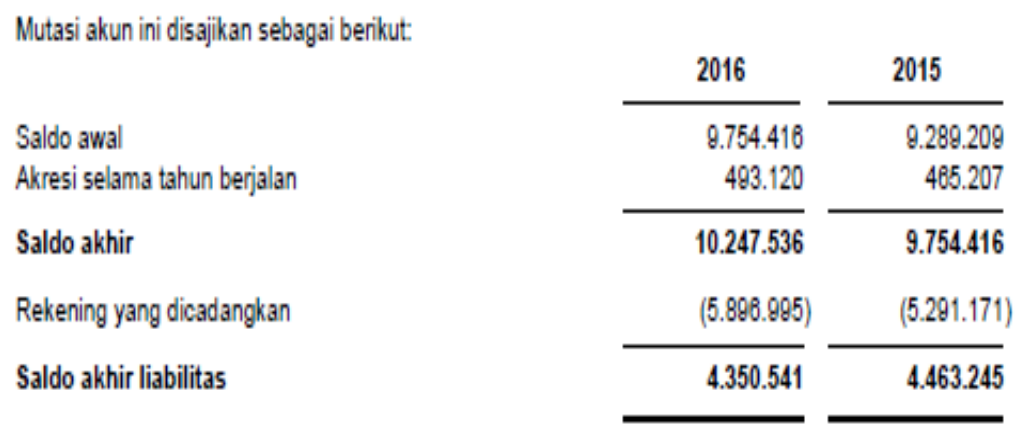

Figure 6 Asset Abandonment and Site Restoration Balance in 2016

The amount of accretion expense during in the current year is calculated by multiplying the initial balance of the asset abandonment and site restoration obligations with the discounted interest rate used by the company in calculating the present value of the current asset value. This accretion expense is an additional burden that comes from the discount rate difference every year. It is from this initial balance and accretion expense that it must then be calculated by the percentage of the number of participating interest companies before making the next step, namely the recording of accounting journals in the company's financial worksheet.

In determining the value of the obligation for asset abandonment and site restoration or ARO (Asset Retirement Obligation) the company merged several calculations from several divisions. In relation to the feasibility audit of the company's financial report or audit report the values recorded in it throughout 2017 can be matched with previous data, namely in 2016, as well as with accounting financial report data which is the main source. So that based on the results of interviews conducted with respondents 1 and respondents 2, then the financial report or audit report of this company can ensure that the accumulated allowance in the report on the company's statement of financial position is sufficient to cover all liabilities arising from the activity of asset abandonment and site restoration. 
Based on the signal theory chosen in this research, where signal theory is a signal for investors to estimate management earnings (Brigham \& Houston, 2001), then if it is linked to this research then with regard to the calculation of recognition of the obligation to demolish and restore assets or ARO (Asset Retirement Obligation) in upstream oil and gas companies can be a signal for investors and management for what they want to achieve in the future. This is because it could be that this obligation is one of the categories of determinants seen in deciding the business strategy in the company itself. This is in accordance with what was said by the respondent, that due to the obligation to demolish and restore assets or ARO (Asset Retirement Obligation) this value is very large, especially for businesses that are in the location of activities in the middle of the sea or offshore so this obligation will definitely be the point measure the company's managerial parties in making decisions (Respondent 1, 2009).

Therefore, the appropriate and reliable calculations can be very influential as managerial information in making decisions. This is also in accordance with what was stated and disclosed by the second speaker, that the obligation for asset abandonment and site restoration or ARO (Asset Retirement Obligation) is not the only factor in making a company's strategic decisions, but becomes one of the factors because of the value information the required liability reserve will be the basis for the company's managerial parties regarding the company's future business strategy (Respondent 2, 2009). Therefore, based on the opinions above, signal theory can be considered appropriate as the initial theory to be developed in this research.

\section{Conclusion}

Based on the research that has been done where the purpose of this study is to be able to provide an overview of the methods that can be used by companies in calculating obligation for asset abandonment and site restoration or ARO that must be paid by the company at the end of the contract period. The formulation of the problem in this research is how the method used by the company in determining the value of the obligation for asset abandonment and site restoration or ARO is appropriate to overcome the potential problems that arise at the end of the contract period. This research is carried out by using mixed-methods in analyzing the findings, so it will find more in-depth and complex findings that will be useful to help the company management in making decisions

The results that can be concluded in this research are that the obligation for asset abandonment and site restoration or ARO (Asset Retirement Obligation) in companies in the upstream oil and gas company is a very material for the company. This obligation is due to the large amount that must be reserved for oil and gas assets owned by the company. This is because the obligation arising as an ARO (Asset Retirement Obligation) is indeed inseparable from the oil and gas assets owned by the company. So based on signal theory, the large recognition of this obligation must be reliable to help managerial parties in determining the company's business strategy, although this obligation is not the only benchmark but because this obligation is very large, this obligation is also an aspect chosen by managerial parties in making decisions.

This obligation must be calculated based on the formula of future value (FV) which is then will be calculated in the present value returned (PV) using the inflation rate and discount interest rate. This obligation is a contingent liability in which the amount is still a provision made by the company. So that even though this obligation is applied accounting based in Indonesian GAAP 57 concerning provisions, contingent liabilities, and contingent assets, but because the company in the upstream oil and gas company uses the land of government concessions, then this obligation is highly probable in the company. Moreover, the obligation for asset abandonment and site restoration has been regulated in a company cooperation contract with the government which must be carried out by the company for the duration of the contract.

The limitation in this research or study is the limited time in collecting data related to this because when this research was carried out the company had not been at the end 
of the contract period so that it could not be known directly whether the reserves that had been carried out during the contract period were actually real at the end of the contract period and can be cover up the obligation for asset abandonment and site restoration. Then, due to time constraints, this study also took the location of research which had a large obligation related to the geographical factor of the assets of the company owned only. Then this research is also limited to opinions based on the workers' side of the company not on the managerial side of the company, due to the reason that this research was conducted not at the end of the contract period, and this study only wanted to know whether the calculation of the recognition had been assessed reliable.

The proposal that can be given in this study for further research is the possibility of research that will discuss the obligation of demolition and restoration of assets seen from the managerial side of the company. As it is known for this obligation the reserved value is quite large so because of that it must be the basis of the assessment benchmarks in the upper managerial stage related to the business processes carried out by the company.

\section{References}

Alexander, E., \& Hiner, R. (2001). Accounting for Asset Retirement Obligation. Retrieved from https://www.journalofaccountancy.com/issues/2001/dec/accountingforassetretir ementobligations.html

Arifin, Z. (2005). Teori Keuangan dan Pasar Modal. Yogyakarta: Ekonosia.

Brady, J., Chang, C. C., Jennings, D. R., Shappard, R., \& Ogden, M. M. (2011). Petroleum Accounting: Principles, Procedures, \& Issues 7th Edition (7th ed.). Texas: Noth Texas University.

Brigham, E. F., \& Houston, J. F. (2001). Manajemen Keuangan. Jakarta: Erlangga.

Ellet, W. (2009). The Case Study Handbook How to Read, Discuss, and Write Persuasively About Cases. Harvard Business School Press. Boston Massachusetts: Harvard Business Scholl Press.

FASB. (2001). Financial Accounting Standard Board.

Glaser, B. G. (1978). Theoritical Sensitivity: Advances in the Methodology of Grounded Theory. Mill Valley, CA: Sociology Press.

Husein, M. (2008). Kontrak Minyak dan Gas Bumi Berazas Keadilan dan Kepastian Hukum. Jakarta: PT Fikahati Aneska.

IAI. (2016). Pedoman Standar Akuntansi Keuangan (PSAK) Revisi 2009. Ikatan Standar Akuntansi Keuangan.

Pemerintah Indonesia. (1974). Peraturan Pemerintah tentang Pengawasan Pelaksanaan Kegiataan Usaha Hulu Minyak dan Gas Bumi (1974). Indonesia.

Kementerian Keuangan Republik Indonesia. (2016). No Title. Retrieved from https://www.kemenkeu.go.id/media/6634/nota-keuangan-rapbn-2016.pdf

Kretarto, A. (2001). Pemasaran dan Komunikasi Keuangan Perusahaan Berbasis 
Kepatuhan. In Pemasaran dan Komunikasi Keuangan Perusahaan Berbasis Kepatuhan (p. 53). Grafiti Pers.

Kusumawati, U. D. (2015). Sudah Ditetapkan DPR Bencana Alam, Lapindo Tak Bisa Dipidana. Retrieved from https://www.cnnindonesia.com/nasional/20150529134709-20-56529/sudahditetapkan-dpr-bencana-alam-lapindo-tak-bisa-dipidana

Lapindo Sidoarjo Report 2014. (2014). Retrieved from http://lapindobrantas.co.id/Lapindo-LUSI-Report-2014-id.pdf

Moleong, L. (2006). Methodology Penelitian Kualitatif. Bandung: Remaja Rosda Karya.

Purba, M. P. (2009). International Financial Reporting Standards Di Indonesia. Yogayakarta: Graha Ilmu.

SKK Migas. (2010). KEP-0139/BP00000/2010/SO. INDONESIA: SKK MIGAS.

Shelley, M., \& Krippendorff, K. (2006). Content Analysis: An Introduction to its Methodology. Journal of the American Statistical Association (Second Edi, Vol. 79). California: Sage Publications, Inc. https://doi.org/10.2307/2288384 